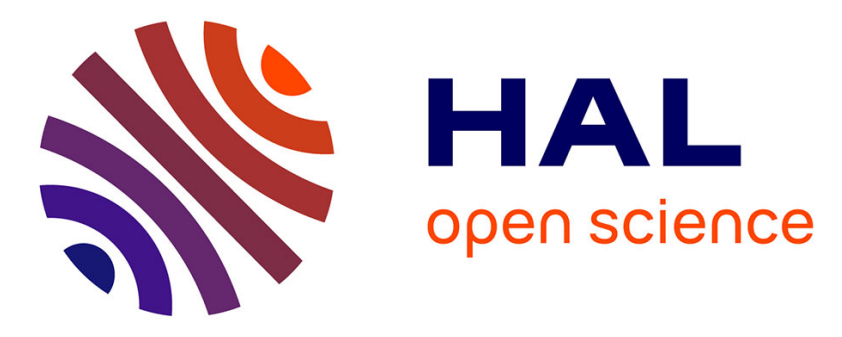

\title{
On soil carbon monitoring networks
}

Dominique D. Arrouays, Ben P. Marchant, Nicolas N. Saby, Jeroen

Meersmans, Claudy C. Jolivet, Thomas T. Orton, Manuel Pascal Martin, Patricia H. Bellamy, Richard M. Lark, Benjamin Louis, et al.

\section{- To cite this version:}

Dominique D. Arrouays, Ben P. Marchant, Nicolas N. Saby, Jeroen Meersmans, Claudy C. Jolivet, et al.. On soil carbon monitoring networks. Global Soil Carbon Conference, International Union of Soil Sciences (IUSS). USA., Jun 2013, Madison, United States. 10.1007/978-3-319-04084-4_6 . hal-02742963

\section{HAL Id: hal-02742963 \\ https://hal.inrae.fr/hal-02742963}

Submitted on 3 Jun 2020

HAL is a multi-disciplinary open access archive for the deposit and dissemination of scientific research documents, whether they are published or not. The documents may come from teaching and research institutions in France or abroad, or from public or private research centers.
L'archive ouverte pluridisciplinaire HAL, est destinée au dépôt et à la diffusion de documents scientifiques de niveau recherche, publiés ou non, émanant des établissements d'enseignement et de recherche français ou étrangers, des laboratoires publics ou privés. 


\section{International Union of Soil Sciences}

\section{Global Soil C Conference}

3-6 June 2013

\section{Program \& Abstracts}

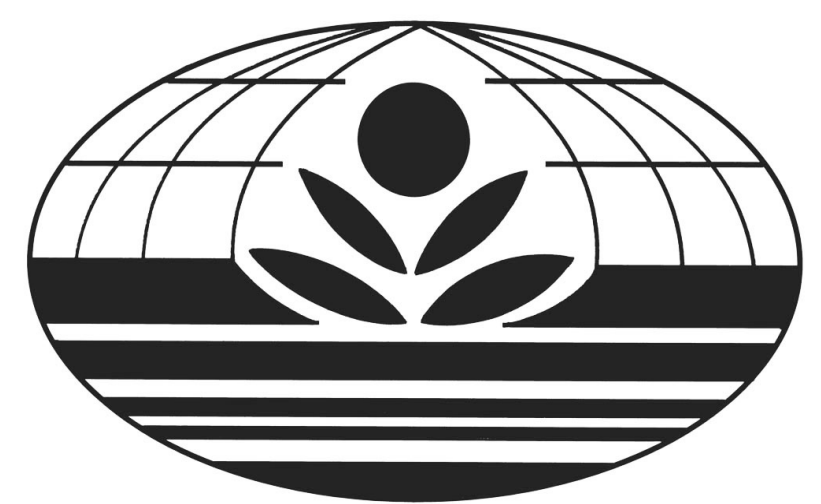

College of

Agricultural \& Life Sciences UNIVERSITY OF WISCONSIN-MADISON

International Union of Soil Sciences 


\title{
On soil carbon monitoring networks
}

\author{
Arrouays, D., B.P. Marchant, N.P.A. Saby, P.H. Bellamy, M.P. Martin, R.M. Lark, J. Meersmans, T.G. Orton, D. Allard, \\ B.P. Louis, C.C. Jolivet \& M. Kibblewhite \\ INRA, InfoSol \\ France \\ (Corresponding email: Dominique.Arrouays@orleans.inra.fr)
}

Abstract

Numerous scientific challenges arise when designing an soil monitoring network (SMN), especially when assessing large areas and soil carbon content and stocks that are driven by numerous controlling factors of various origins and scales. Different broad approaches to the establishment of SMNs are reviewed. National frameworks for soil monitoring exist in numerous countries and especially in most member states of the European Union. However, while some countries have achieved uniformity in methodology and coverage, this is far from common even among national systems. In addition to achieving harmonization, there are many generic issues that must be addressed by scientists when establishing and operating SMNs, including the requirement for these to be effective for different soil-systems. Of particular importance is the requirement for SMNs to detect change in soil $\mathrm{C}$ over relevant spatial and temporal scales with adequate precision and statistical power. We present several examples addressing this scientific issue and summarize the main findings of previous reviews on this topic. It is essential to establish an adequate sampling protocol that can be applied rigorously at each sampling location and time. We make some recommendations regarding the within-site sampling of soil. Different statistical methods should be associated with the different types of sampling design. At the global scale the question of sampling and testing method harmonization remains a very difficult issue. The establishment of benchmark sites devoted to harmonization and inter-calibration is advocated as a technical solution. We present a case study in France addressing crucial scientific issues such as how many calibration sites are necessary and how to locate them.

Notes 